\title{
Analysis of Economic Inequality and Human Development: A Case Study of West Sumatra Province in 2015-2019
}

\author{
Muhammad Fikram Palembang, Ismanita Prahara, Muhammad Rizky Shiddiq Nugraha, Relinda Dewi Astabella, Revia \\ Ardyaning Pramesti, Dimas Maula Hayat, and Ratih Fitria Putri* \\ Department of Environmental Geography, Faculty of Geography, Gadjah Mada University, Indonesia
}

\begin{abstract}
West Sumatra Province is one of the provinces with diverse human resources. This situation causes the need for human resource management to encourage economic growth. This study aims to identify economic development, economic inequality and human development, as well as the relationship between economic inequality and human development in West Sumatra Province in 2015-2019. The basic data used in the analysis are GRDP and the Human Development Index (IPM) using quantitative descriptive analysis methods. Economic development was analyzed using Location Quotient (LQ) and Klassen typology, while economic inequality was using Entropy Theil. The research showed that the Klassen typology results were dominated by developed but slow regions which amounted to nine regencies/cities and based on LQ showed that urban areas had a base sector in the secondary and tertiary sectors, while rural areas had a base sector in the tertiary sector. The HDI has increased which is accompanied by an increase in entropy, indicate that high GRDP is not evenly distributed. In addition, there is a strong relationship between economic inequality in terms of GRDP per capita and HDI. This shows an increase in economic growth that triggers improvements in the health and education sectors so that it has a good impact on the quality of human development but needs an even distribution.
\end{abstract}

\section{Introduction}

Economic growth in the development process is influenced by the quality of resources in a human region. Simply put, the better the quality of human resources, the better the regional economic growth. The focus of economic development in order to achieve better development is focused on reducing poverty, inequality, increasing capital income, and reducing unemployment [1]. One of the causes of economic development being hampered is because one of these focuses is still difficult to achieve, the problem is economic inequality. This problem cannot be separated from human development, because good human development will lead to good economic growth. In accordance with statement by the United Nations Development Program (UNDP) through the concept trickle down which explains that economic development will lead to human development, on the contrary in the concept of virtuous circle it explains that human development will lead to economic development. The two components are interconnected as described in the concept of a triangle circle, if one of these components goes well then the other components will follow [2].

West Sumatra Province is located along the west coast of the central part of Sumatra Island, bordered by the Bukit Barisan plateau in the east, and a number of offshore islands in the south part. Amount of 5.534.472

\footnotetext{
*Corresponding author: ratihfitria.putri@ugm.ac.id
}

people spread over 19 administrative areas consisting of 7 cities and 12 regencies. Most of the population in West Sumatra Province work in agriculture, which is 36,22 percent. Furthermore, other sectors that dominate are the trade sector amount of 19,10 percent [3]. The geographical condition of West Sumatra Province which is not entirely in the form of highlands makes this area dominated by the agricultural sector. The dominance of the agricultural sector in this province triggers economic growth and human development to become increasingly complex and diverse. Based on previous research [4], there was an increase in development inequality in West Sumatra was influenced by economic growth, investment, labor and balancing funds. These conditions encourage the economic growth of West Sumatra Province which needs more attention in order to achieve the goals of regional development to improve the welfare of the community and the quality of regional human resources [5].

An analysis of inequality and human development in West Sumatra Province is needed to evaluate the level of economic and human growth in the area. The results of the analysis can be used as an evaluation material for human resource management and economic development. Therefore, the purpose of this study was to determine the condition of economic development, economic inequality and human development and to determine the relationship between economic inequality and human development in West Sumatra Province from 2015 to 2019. 


\section{Method}

The research was carried out in West Sumatra Province which consisted of 12 regencies involving Kepulauan Mentawai, Pesisir Selatan, Solok, Sijunjung, Tanah Datar, Padang Pariaman, Agam, Lima Puluh Kota, Pasaman, Solok Selatan, Dharmasraya, Pasaman Barat and 7 cities involving Padang, Solok, Sawah Lunto, Padang Panjang, Bukittinggi, Payakumbuh and Pariaman (Fig. 1). The research was conducted using a descriptive-quantitative analysis method by processing secondary data for 2015-2019. The data used in this study consist of secondary data published by Bureau of Statistik (BPS) Indonesia and West Sumatra, involving data of Gross Regional Domestic Product (GRDP) by regencies/city in West Sumatra, Gross Domestic Product (GDP) of Indonesia, number of population, and human development indicators through Human Development Index (HDI). The inequality of West Sumatra measured by Entropy Theil, Location Quotient (LQ), and Klassen Typology. Furthermore, correlation between economic inequality and human development was analyzed with Pearson Correlation.

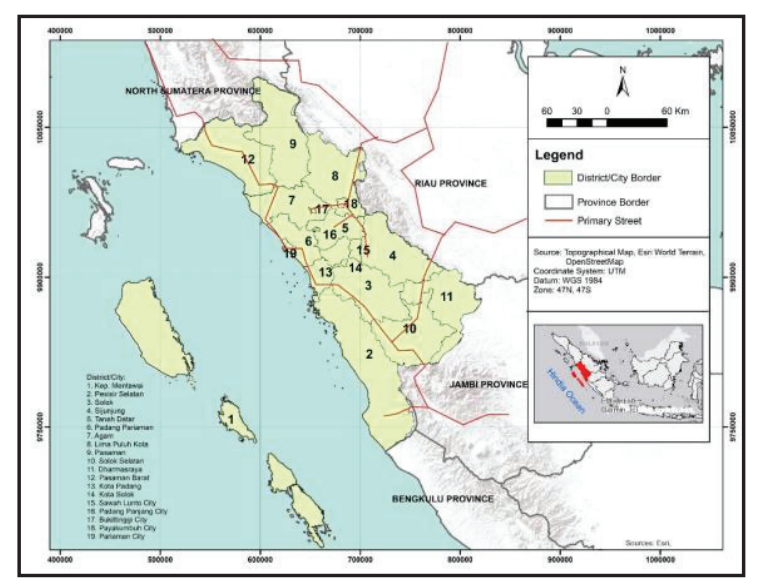

Fig 1. Administration Map of West Sumatra

\subsection{Entropy Theil}

Theil Entropy Index is used to measure economic inequality between regions [6]. Economic inequality in West Sumatra Province is measured using the Theil Entropy Index formula [7] as follows:

$$
\text { I Theil in }=\Sigma(y i / Y) \times \log [(y i / Y) /(x i / X)]
$$

$$
\begin{array}{ll}
\text { Description: } \\
\text { I Theil in }
\end{array}
$$

Inequality
I Theil out $=\Sigma(y / Y) x \log [(y / Y) /(x / X)]$

$\begin{array}{ll}\text { Description: } & \\ \text { I Theil out } & \begin{array}{l}\text { : Economic inequality outside the } \\ \text { region }\end{array} \\ \mathrm{Y} & \begin{array}{l}\text { : Gross Domestic Product (GDP) per } \\ \text { capita of the province }\end{array} \\ \mathrm{X} & : \text { Population of the province } \\ \mathrm{Y} & : \text { Average GDP per capita of the } \\ & \text { country } \\ \mathrm{X} & : \text { Population of the country }\end{array}$

The greater Theil Entropy indicates the higher economic inequality between regions. On the other hand, the smaller Theil Entropy Index indicates low economic inequality between regions.

\subsection{Location Quotient (LQ)}

Location Quotient (LQ) is an indirect approach that is used to measure the performance of the base sector which is the growth driver by measuring the relative concentration or degree of specialization of economic activity through a comparative approach to the economy of a region [8]. The formula used to calculate LQ, namely:

$\mathrm{LQ}=(\mathrm{Vik} / \mathrm{Vk}) /(\mathrm{Vip} / \mathrm{Vp})$

Description:

Vik : GRDP Agricultural sector Regency

Vk : GRDP Total all sectors in Regency

Vip : GRDP Agricultural sector Province

Vp : GRDP Total all sectors Province

The results of the LQ calculation produce 3 criteria, namely:

- $\mathrm{LQ}>1$, meaning that sector $\mathrm{i}$ is the basis or source of economic growth in region $\mathrm{k}$.

- $\mathrm{LQ}=0$, meaning that sector $\mathrm{i}$ is not the base sector in region $\mathrm{k}$.

- $\mathrm{LQ}<1$, meaning that sector $\mathrm{i}$ is not the base sector or a source of economic growth in region $\mathrm{k}$.

\begin{tabular}{|c|c|c|}
\hline & $\begin{array}{c}Y \text { area }>Y \\
\text { reference }\end{array}$ & $\begin{array}{c}\mathbf{Y} \text { area }<\mathbf{Y} \\
\text { reference }\end{array}$ \\
\hline $\begin{array}{c}\mathbf{r} \text { area }>\mathbf{r} \\
\text { reference for }\end{array}$ & $\begin{array}{l}\text { Advanced and } \\
\text { fast-growing } \\
\text { region }\end{array}$ & $\begin{array}{l}\text { Potential } \\
\text { region or can } \\
\text { still grow }\end{array}$ \\
\hline
\end{tabular}

\subsection{Klassen Typology}

The Klassen typology is carried out by comparing the regional economic growth with the economic growth that is the reference in the area and comparing the regional GRDP per capita with the GRDP per capita which is the reference for the region [9]. The Klassen typology can be shown in the following matrix [10]:

Table 1. Klassen Typology Matrix. 


\begin{tabular}{|c|c|c|}
\hline & rapidly \\
\hline $\begin{array}{r}\mathbf{r} \text { region }<\mathbf{r} \\
\text { reference for }\end{array}$ & $\begin{array}{c}\text { Advanced } \\
\text { region but } \\
\text { depressed }\end{array}$ & $\begin{array}{c}\text { The region is } \\
\text { relatively } \\
\text { lagging } \\
\text { behind }\end{array}$ \\
\hline
\end{tabular}

Description:

Y region : GRDP per capita area

Y reference : GRDP per capita which is the reference for the region

$r$ region : Regional economic growth

$r$ reference : Growth economy is the reference area of the

Calculation of Typology Klassen results will produce four categories of areas:

- Fast advancing and growing rapidly.

- Regions that are fast progressing but slow to develop.

- Developing areas, in contrast to potential areas.

- Lagging regions.

\subsection{Pearson Correlation}

Correlation is used to determine the relationship between variables. Pearson correlation has a value ranging from -1 to 1 , with the following formula:

$\mathrm{r}=\frac{x y-\frac{\left(\sum x \sum y\right)}{n}}{\sqrt{\left(\sum x \frac{\left(\sum x\right)^{2}}{n}\right)\left(\sum y^{2} \frac{\left(\sum y^{2}\right)}{n}\right)}}$

The results of the Pearson correlation are described by the notation $r$ with the criteria in Table 2 below [11]:

Table 2. Criteria for the results of the Pearson Correlation.

\begin{tabular}{|c|c|}
\hline r value & Criteria \\
\hline $0.00-0.19$ & Very weak correlation \\
\hline $0.20-0,49$ & Weak correlation \\
\hline $0.50-0.69$ & Fair correlation \\
\hline $0.70-0.79$ & Strong correlation \\
\hline $0.80-1.00$ & Very strong correlation \\
\hline
\end{tabular}

\section{Result and Discussion}

\subsection{Economic Inequality in West Sumatra Province}

\subsubsection{Entropy Theil}

Theil Entropy Index explains the economic inequality of a region based on per capita income. If the value is closer to 0 (zero), the distribution of income is more equal [12]. Theil Entropy Index measures economic inequality inside the Province of West Sumatra and economic inequality outside the Province of West Sumatra. Based on the calculation of the Theil Entropy Index outside the Province of West Sumatra in 20152019 using the variables of GRDP and the population of the Province of West Sumatra then compared to the GRDP and the total population of Indonesia, it is known that the Theil Entropy Index of the Province of West Sumatra is increasing.

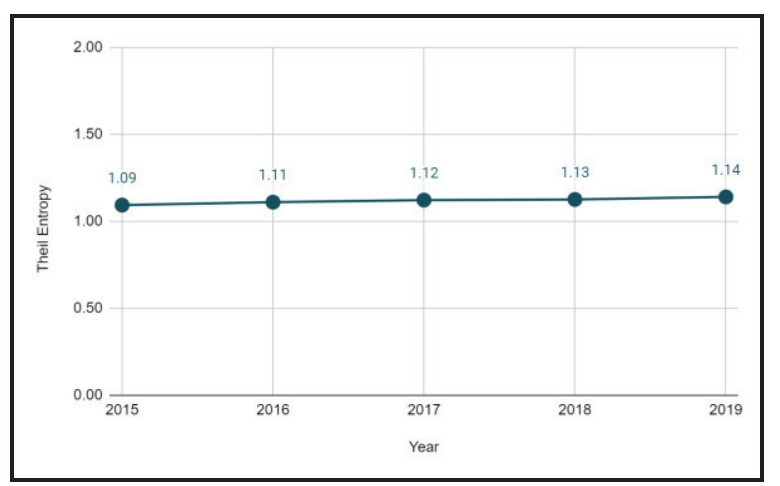

Figure 2. Theil Entropy Index of West Sumatra Province 2015-2019.

Figure 2 shows the increase in the Theil Entropy Index of West Sumatra Province in 2015-2019. Theil Entropy Index of West Sumatra Province increased by 0.05 for 5 years (2015-2019). The increase in Theil's Entropy Index indicates that the economic inequality of West Sumatra Province against other provinces in Indonesia is getting bigger. The value of the Entropy Index is influenced by GRDP and population. The large GRDP and small population cause the low value of Theil's Entropy. A low Theil Entropy Index indicates low economic inequality. GRDP per capita of West Sumatra Province increased in 2015-2019, however, its value is still below the average GDP per capita of Indonesia. Thus, the GRDP per capita of West Sumatra Province is still below the GRDP per capita of other provinces. The value of GRDP per capita of West Sumatra Province and the average GDP per capita of Indonesia can be seen in Figure 3.

Table 3. GRDP per capita of West Sumatra Province and GDP per capita of Indonesia

\begin{tabular}{|c|c|c|}
\hline Year & $\begin{array}{c}\text { GDRP of West } \\
\text { Sumatra }\end{array}$ & $\begin{array}{c}\text { GDP of } \\
\text { Indonesia }\end{array}$ \\
\hline $\mathbf{2 0 1 5}$ & $27,044.14$ & $38,138.93$ \\
\hline $\mathbf{2 0 1 6}$ & $28,164.93$ & $39,246.29$ \\
\hline $\mathbf{2 0 1 7}$ & $29,310.69$ & $40,495.93$ \\
\hline $\mathbf{2 0 1 8}$ & $30,477.76$ & $41,997.49$ \\
\hline $\mathbf{2 0 1 9}$ & $31,669.59$ & $43,195.44$ \\
\hline
\end{tabular}


Economic inequality between regencies/cities in the Province of West Sumatra is calculated using the Theil-in Entropy Index (I Theil In). Based on the results, it is known that the Theil Entropy Index of regencies/cities in West Sumatra Province is at a low to moderate level. Urban (city) has higher economic inequality than rural (regency). Regencies/cities in West Sumatra Province that have a low Theil Entropy Index are South Pesisir Regency, Solok Regency, Tanah Datar Regency, Agam Regency, Pasaman Regency, and Pasaman Barat Regency, while regencies/cities that have a moderate Theil Entropy Index are Sijunjung Regency, Padang Pariaman Regency, Lima Puluh Kota Regency, South Solok Regency, Dharmasraya Regency, Padang City, Solok City, SawahLunto City, Padang Panjang City, Bukittinggi City, Payakumbuh City dan Pariaman City. The spatial distribution of Theil Entropy Index levels in West Sumatra Province can be seen on the Theil Entropy Index Map of West Sumatra Province (Figure $3)$.

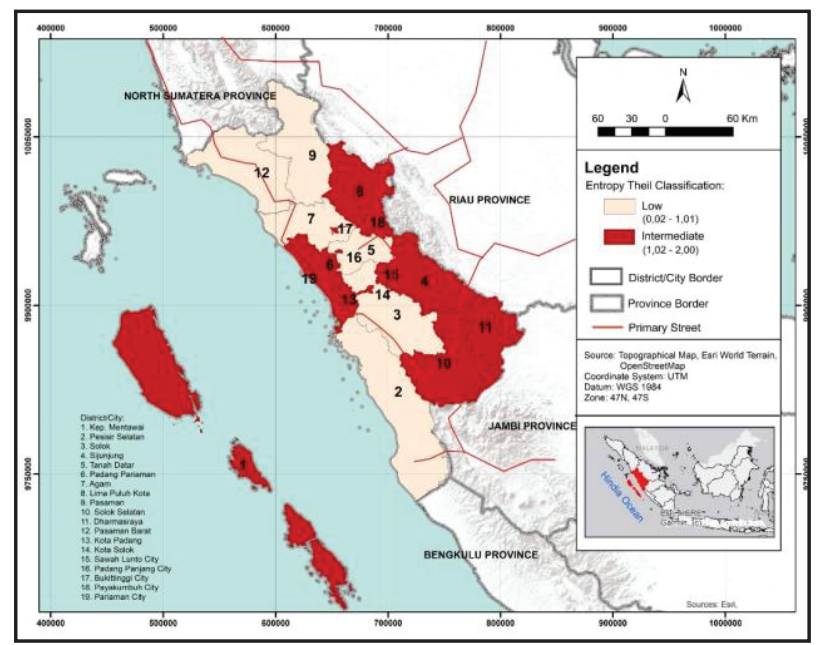

Fig. 3. Theil Entropy Index Classification Map of West Sumatra Province by Regency/City 2015-2019.

\subsubsection{Location Quotient (LQ)}

Economic inequality arises due to the absence of equity in economic development which can be caused by differences in the main pillars of the economy as well as differences in the base sector in each region. The basic sector is a sector that has an important role in economic growth because it is directly related to the demand for goods and services from outside the region. Economic basis theory states that the rate of economic growth of a region is determined by the magnitude of the increase in exports from that region. Thus, basic activities have an important role as the main driver of the economy in a region. Economic inequality based on differences in the base sector in West Sumatra Province can be seen through the Location Quotient value.

Table 4. The results of the LQ calculation by regencies/cities in West Sumatra Province in 2015-2019.

\begin{tabular}{|l|c|c|c|}
\hline Regency/Municipal & $\begin{array}{c}\text { Prima } \\
\text { ry } \\
\text { Sector }\end{array}$ & $\begin{array}{c}\text { Secon } \\
\text { dary } \\
\text { Sector }\end{array}$ & $\begin{array}{c}\text { Tertiar } \\
\mathbf{y} \\
\text { Sector }\end{array}$ \\
\hline Kepulauan Mentawai & 1,73 & 0,29 & 0,72 \\
\hline South Pesisir & 1,55 & 0,80 & 0,80 \\
\hline Solok Selatan & 1,59 & 0,54 & 0,82 \\
\hline Sijunjung & 1,64 & 0,32 & 0,84 \\
\hline Tanah Datar & 1,25 & 1,16 & 0,87 \\
\hline Padang Pariaman & 1,03 & 1,24 & 0,95 \\
\hline Agam & 1,28 & 1,18 & 0,85 \\
\hline Limapuluh Kota & 1,56 & 0,75 & 0,80 \\
\hline Pasaman & 1,92 & 0,46 & 0,70 \\
\hline South Solok & 1,46 & 0,53 & 0,88 \\
\hline Dharmasraya & 1,41 & 0,58 & 0,90 \\
\hline West Pasaman & 1,57 & 0,38 & 0,57 \\
\hline Padang City & 0,29 & 1,41 & 1,24 \\
\hline Solok City & 0,23 & 0,55 & 1,41 \\
\hline Sawah Lunto City & 0,57 & 1,38 & 1,12 \\
\hline Padang Panjang City & 0,20 & 1,02 & 1,35 \\
\hline Bukittinggi City & 0,05 & 0,73 & 1,46 \\
\hline Payakumbuh City & 0,27 & 0,58 & 1,39 \\
\hline Pariaman City & 0,73 & 0,79 & 1,15 \\
\hline
\end{tabular}

Based on Table 4 the results of LQ calculations in Sumatra Province West 2015-2019 shows that the primary sector is the economic base sector in the Kepulauan Mentawai, South Pesisir, Solok, Sijunjung, Tanah Datar, Padang Pariaman, Agam, Limapuluh Kota, West Pasaman, South Solok, Dharmasraya, and West Pasaman. It is because the primary sector has an LQ $>1$ index, meaning that the regency is more specialized or more dominant in the primary sector than at the provincial level, where this sector in the economy has a comparative advantage and is categorized as a leading base sector. The secondary sector is the economic base sector in Tanah Datar Regency, Padang Pariaman Regency, Agam Regency, Padang City, Sawah Lunto City, and Padang Panjang City because the secondary sector has an LQ index $>1$, meaning that the primary sector is the basis or source of economic growth, where these regencies/cities are more specialized in the secondary sector than at the provincial level. While the tertiary sector into sectors 
of the economic base in the city of Padang, Solok, Sawah Lunto, Padang Panjang, Bukittinggi, Payakumbuh and Kota Pariaman for the tertiary sector has LQ> 1, meaning that the tertiary sector into the base or be a source of economic growth, which the regency/city more specialized in the tertiary sector than at the provincial level.

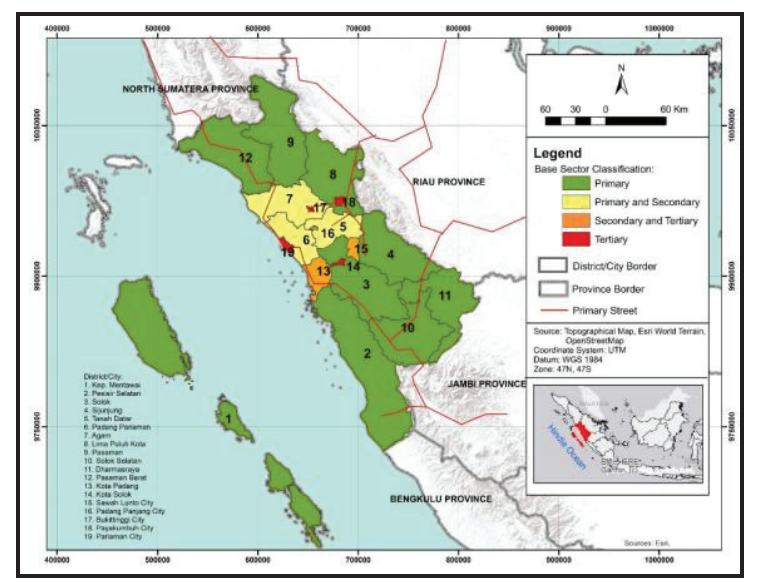

Fig 4. Base sector distribution map in West Sumatra Province.

Based on the results of the analysis of the economic base sector as shown in Figure 4 the distribution map of the base sector, it was found that there is a very significant difference between urban and rural areas, where urban areas have an economic base sector in secondary and tertiary sectors, while rural areas have an economic base sector in the primary sector. This is due to differences in the content of natural resources, geographical conditions, the rate of infrastructure growth as well as differences in demographic conditions as well as differences in urban and rural areas. Rural areas contain natural resources and geographical conditions that are suitable for the development of the primary sector (agriculture, livestock, fisheries and forestry), while urban areas have a lot of infrastructure development and have human resources who have high knowledge, so that the sector that develops a lot are industry, trade and services sectors.

\subsubsection{Klassen Typology}

An area can be said to be developed and developing, one of which is by using GRDP data, which is the amount of added value produced by all business units in an area or is the total value of goods and services produced by all economic units in a region [13]. Then to see the developments in an area, it can be seen from the development of the GRDP of the previous year with the current year. Then to find out whether the area is included in the category of developed, developing or underdeveloped, the Klassen typology analysis can be used. West Sumatra Province has 19 regencies and cities. The results of the calculation of the klassen typology of each city regency in the province of West Sumatra with the reference value used is the average of the whole, or the value of the GRDP and economic growth of the province of West Sumatra it self from 2015-2019, has a distribution as shown in Figure 5. Graph distribution category the number of regencies/cities in West Sumatra Province from 2014 to 2019 .

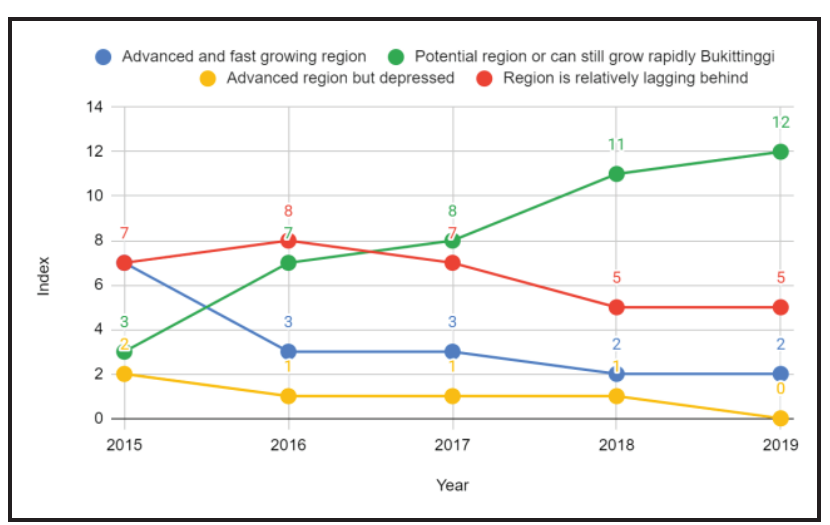

Fig 5. Graph of the distribution of categories for the number of regencies/cities in West Sumatra Province 2014-2019.

Based on the graph, it can be seen that areas that are very prime in terms of progress and development have decreased every year. The decline occurred in seven regencies/cities in West Sumatra Province in 2015 and the remaining two regencies/cities in 2019. This also occurred in potential regions or can still grow rapidly and relatively lagging behind regions, although the decline was not too significant. The decline in the number of regencies/cities classified as advanced and fast-growing regions in underdeveloped areas, in 2015 from eight regencies/cities to only five regencies/cities in 2019. The decline in relatively lagging behind regions which originally had two regencies/cities in 2015 became none at all in 2019. Meanwhile, what has increased rapidly is the number of potential regions, in the sense that the area is developed but has slow economic growth, initially there were only three regencies/cities in 2015 increasing to 12 regencies/cities in 2019.

The decline in the advanced and fast-growing region showed a negative shift in value. This is because the number of very prime areas has decreased, of course, it is an indication of problems in the regency and city. However, in the category of potential region or can still grow rapidly and relatively lagging behind region, the decline was followed by an increase in advanced regions but depressed. This is a shift in value in a positive direction. It means the area has a GRDP that is above the reference value so that it is included in the category of developed regions.

One of the factors that makes it difficult to maintain an area in prime condition is the value of GRDP. Most regions, in fact, experienced a decline to potential conditions with high GRDP values but slowing economic growth. If the value of GRDP is low and there is a significant increase in the following year, it will certainly make a spike in economic growth in an area. So that when the GRDP value is already in the advanced category, or greater than the reference 
GRDP, it will certainly be difficult to continue to maintain economic growth from the existing GRDP. When GRDP is high, it will tend to experience stability in which economic growth is calculated as a percentage. This of course causes the existing percentage to decrease even though the magnitude of the value increases. This increase resulted in stable growth and was below the reference value, but the existing GRDP was already above the reference value, so that those in the prime sector with advanced GRDP and fast growth slowly fell to potential sectors with advanced GRDP but slow economic growth.

Table 5. Result of Classification Klassen Typology based on the rate of GRDP and GRDP per capita by Regency / City in West Sumatra Province from 2015 to 2019.

\begin{tabular}{|c|c|c|}
\hline \multirow{1}{*}{$\mathbf{r 1}>\mathbf{r}$} & $\begin{array}{c}\text { Y1 }>\mathbf{y} \\
\text { Quadrant I } \text { Advanced } \\
\text { and fast growing } \\
\text { region }\end{array}$ & $\begin{array}{c}\text { Y1<y } \\
\text { Potential region or } \\
\text { can still grow } \\
\text { rapidly }\end{array}$ \\
\cline { 2 - 3 } & $\begin{array}{c}\text { Bukittinggi City and } \\
\text { Padang Panjang City }\end{array}$ & Pasaman Barat \\
\hline \multirow{1}{*}{$\mathbf{r 1}<\mathbf{r}$} & $\begin{array}{c}\text { Quadrant III } \\
\text { Advanced region but } \\
\text { depressed }\end{array}$ & $\begin{array}{c}\text { Quadrant IV The } \\
\text { region is relatively } \\
\text { lagging behind }\end{array}$ \\
\cline { 2 - 3 } & $\begin{array}{c}\text { Kepulauan Mentawai, } \\
\text { Padang Pariaman, } \\
\text { Agam, Dharmasraya, } \\
\text { Padang City, Solok } \\
\text { City, Sawah Lunto } \\
\text { City, Payakumbuh } \\
\text { City, Pariaman City }\end{array}$ & $\begin{array}{c}\text { South Pesisir, } \\
\text { Solok, Sijunjung, } \\
\text { Tanah Datar, } \\
\text { Limapuluh Kota, } \\
\text { Pasaman, South } \\
\text { Solok }\end{array}$ \\
\hline
\end{tabular}

Table 5 shows the Klassen typology category in each regency and city as a result of the average category in 2015-2019 in the province of West Sumatra. Most of the regencies and cities in the province of West Sumatra are in the III Quadrant and there are only two cities that fall into the prime category or the I quadrant. This is only natural because both are big cities in West Sumatra Province. While in the second quadrant there is only one regency, the rest are in the last quadrant, namely the fourth quadrant which is the lagging quadrant, and the average for the last five years shows that there are seven regencies that fall into that category.

\subsection{The Conditions of Human Development in the Province of West Sumatra}

Discussion on the Human Development Index (HDI) in the Province of West Sumatra can be reviewed on the conditions of HDI in each regency. Based on the calculation results, in general, all regencies/cities in 2016-2019 experienced an increase in the index. The increase in HDI during that period (Figure 6) was also accompanied by a higher theil entropy (Figure 2) and increase of GRDP (Figure 7). This phenomenon indicates a high value of GRDP does not always indicate a low Theil Entropy. In other words, a high GRDP indicates that there is no even distribution of income in West Sumatra Province. This seems to be against the basic concept of calculating HDI. The HDI calculation takes into account economic indicators so that the higher the economic status, the higher the HDI obtained. This phenomenon indicates that there are indicators that are more dominant than economic indicators, considering that there are indicators of education and health in the HDI calculation.

The HDI condition of each regency contributes to the HDI in general at the provincial level. Figure 7 explains that in the period 2015-2019 in West Sumatra increased levels of HDI. At first glance, the increase in HDI at both the provincial and regency levels is good news for development in this province, although there is a note for development in this province. The note in question is economic inequality that still occurs and has an increasing trend every year.

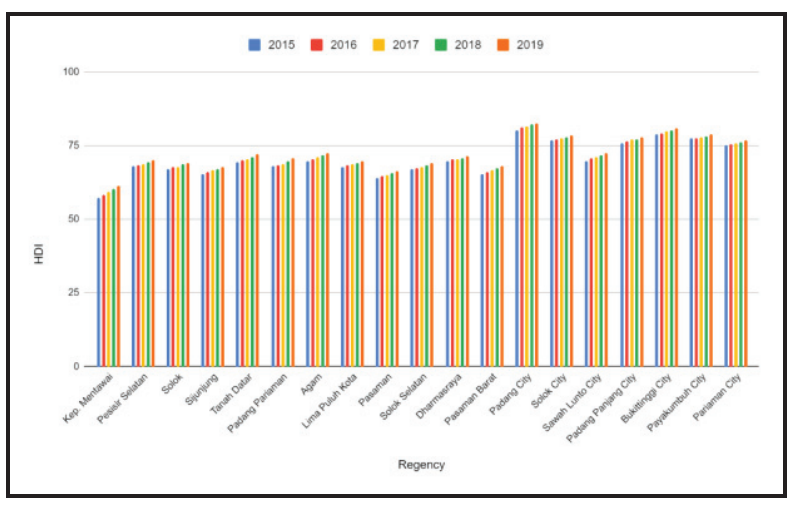

Fig 6. Graph of the Human Development Index (HDI) of West Sumatra Province in 2015-2019.

\subsection{Relationship between Economic Development and Human Development in the Province of West Sumatra}

Economic growth as described by GRDP per capita has a relationship with human development described by HDI. Economic growth and human development there is a two-way relationship, where economic growth increases human development. However, on the other hand, increasing human development makes it possible to increase economic growth [14] [15]. This happened in West Sumatra Province which can be seen in Figure 6. The figure shows the pattern of per-capita GRDP development and human development in West Sumatra Province from 2015 to 2019. This condition indicates that economic development will affect the increase in human development, or otherwise, the increase in human development will affect the increase in economic development. 


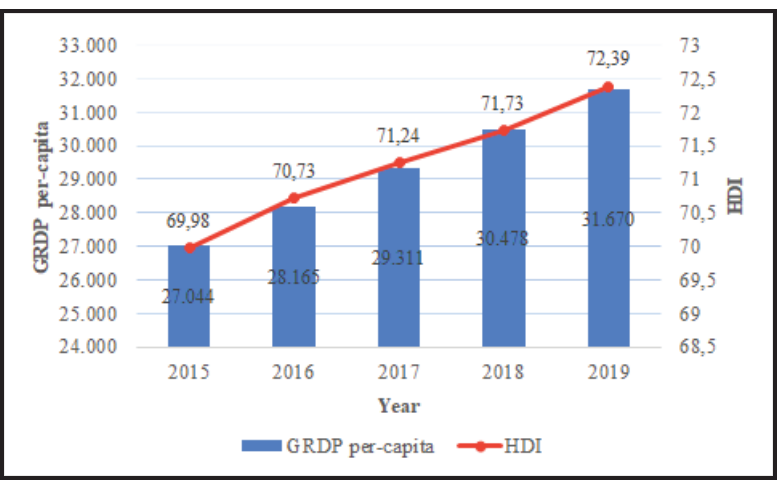

Fig 7. Graphic of GRDP per-capita and HDI in West Sumatra Province 2015-2019.

The relationship between economic development and human development is analyzed based on regencies/cities in West Sumatra Province. The analysis was carried out using Pearson correlation with GRDP as a variable of economic development and HDI as a variable of human development. This analysis was conducted to determine the increase in the economic development of each region will affect the increase in human development in the region. The following are the results of the Pearson GRDP correlation with HDI in West Sumatra Province from 2015 to 2019.

Table 6. Pearson Correlation Results between economic development variables (GRDP) and human development (HDI) by regency/city in West Sumatra Province 2015-2019.

\begin{tabular}{|l|c|c|}
\hline \multicolumn{1}{|c|}{ Regency/city } & $\begin{array}{c}\text { Pearson } \\
\text { Coefficient }\end{array}$ & Significancy \\
\hline Kepulauan Mentawai & 1,000 & 0,000 \\
\hline South Pesisir & 0,986 & 0,002 \\
\hline Solok & 0,989 & 0,001 \\
\hline Sijunjung & 0,995 & 0,000 \\
\hline Tanah Datar & 0,986 & 0.002 \\
\hline Padang Pariaman & 0,962 & 0,009 \\
\hline Agam & 0,999 & 0,000 \\
\hline Limapuluh Kota & 0,992 & 0,001 \\
\hline Pasaman & 0,991 & 0,001 \\
\hline South Solok & 0,995 & 0,000 \\
\hline Dharmasraya & 0,977 & 0,004 \\
\hline West Pasaman & 0,998 & 0,000 \\
\hline Padang City & 0,996 & 0,000 \\
\hline Solok City & 0,994 & 0,001 \\
\hline Sawahlunto City & 0,996 & 0,000 \\
\hline
\end{tabular}

\begin{tabular}{|l|c|c|}
\hline \multicolumn{1}{|c|}{ Regency/city } & $\begin{array}{c}\text { Pearson } \\
\text { Coefficient }\end{array}$ & Significancy \\
\hline Padang Panjang City & 0,993 & 0,001 \\
\hline Bukittinggi City & 0,994 & 0,000 \\
\hline Payakumbuh City & 0,971 & 0,006 \\
\hline Pariaman City & 0,996 & 0,000 \\
\hline
\end{tabular}

According to the Pearson correlation analysis presented in Table 6 , it shows that the correlation between GRDP per capita and the development index has a strong relationship and is statistically significant because both are at a significance value less than equal to 0,05 . It means high economic growth causes human development to also increase. This happens because HDI is one of the indicators that influence economic growth, therefore the Human Development Index (HDI) has a big influence on increasing economic growth. This is reinforced by the results of previous research [16], economic growth and human development have a mutually influencing relationship.

Based on the results of the analysis of the relationship between economic growth and human development, each regency/city in West Sumatra Province in 2015-2019 can be used as a basis for determining the direction of development and policies that can be taken by the government to improve regional development, especially for regencies/cities that are relatively less developed. Therefore, there is a need for a balance between economic growth and human development. The balance of the two can create an even distribution of income and the allocation of public spending in the fields of education and health can improve human development so as to increase regional development.

\section{Conclusion}

The results of this study indicate that the condition of economic development based on the calculation of Location Quotient (LQ) in urban areas has a base sector in the secondary and tertiary sectors, while rural areas have a leading base sector in the tertiary sector. Economic development from Klassen's typology results, West Sumatra Province there are two cities that are included in developed and developing areas, one district is included in the slow growing developed area, eight districts/cities are classified as developing areas, and seven districts/cities are classified as underdeveloped areas. Economic inequality in terms of the Theil Entropy Index of Sumatra Province against other Provinces in Indonesia is increasing in 20152019. This condition is caused by GDP per capita of West Sumatra Province in 2015-2019 is still below Indonesia's GDP per capita although it has increased every year. In addition, this study analyzed the conditions of human development obtained by increasing the index. The increase in HDI during that 
period was also accompanied by a higher theil entropy which illustrates that high GRDP doesn't indicate an even distribution of income in the Province of West Sumatra. Economic development has a strong relationship with the Human Development Index based on the results of the Pearson correlation test. This relationship shows that an increase in economic growth causes an increase in the Human Development Index in each regency/city in West Sumatra Province. This condition is caused by increased economic growth triggering improvements in health and education aspects so that it has a good impact on the quality of human development.

\section{Acknowledgement}

This Research is part of the lecture block of Human and Economic Resource Analysis held by Department of Environmental Geography, Faculty of Geography, Universitas Gadjah Mada. We would like to thank for the guidance to all of lecturer of Human and Economic Resource Analysis.

\section{References}

1. M. P. Todaro, S. C. Smith. Economic Growth, $11^{\text {th }}$ Edition (Prentice Hall, New Jersey, 2011)

2. UNDP. Human Development Report 2001, Making New Technologies Work for Human Development (Oxford University Press, New York, 2001)

3. Badan Pusat Statistik. Provinsi Sumatra Barat dalam Angka 2021 (BPS, Yogyakarta, 2021)

4. B. Bakri, S. Syafrizal, H. Aimon. Analisis Ketimpangan Pembangunan antar Kabupaten/Kota di Sumatra Barat dan Kebijakan Penanggulangannya. Jurnal Kajian Ekonomi, 4(7). (2016)

5. World Bank. World Development Report: The State in Changing World (The World Bank, New York, 1997)

6. H. Theil. Economics and Information Theory. (North-Holland Publishing Company, Amsterdam, The Netherlands, 1967)

7. G. L. Ying. China's Changing Regional Disparities during the Reform Period. Economic Geography, 24, 59-70 (2000)

8. L. Arsyad. Ekonomi Pembangunan (UPP STIM YKPN, Yogyakarta, 2010)

9. E.S. Rahayu. Aplikasi Tipologi Klassen Pada Strategi Pengembangan Subsektor Pertanian Tanaman Pangan di Kabupaten Boyolali. Journal of Rural and Development, 1 (2010)

10. T. Widodo. Perencanaan Pembangunan: Aplikasi Komputer (Era Otonomi Daerah) (UPP STIM YKPN, Yogyakarta, 2006)

11. Suliyanto. Ekonomika Terapan: Teori dan Aplikasi dengan SPSS. (Andi, Yogyakarta 2014)
12. A. Nalle, H. Wulakada. Analysis of Economic Growth and Inequality Based On Economic Geographic Review in East Nusa Tenggara. DOARJ - Directory of Academy Resource Journal, 3 (9): 62-75 (2019)

13. Badan Pusat Statistik. Provinsi Sumatra Barat dalam Angka 2010 (BPS, Yogyakarta, 2010)

14. G. Ranis, F. Stewart, A. Ramirez. Economic growth and human development. World development, 28, 197-219 (2000)

15. N. E. A. M. T,. U. Daniela-Mihaela, C. OanaGeorgiana. Correlations between human development and economic growth. Annals of the „Constantin Brâncuşi” University of Târgu Jiu, Economy Series. Volume 1, 118-122 (2015)

16. E. Elistia, \& B. A. Syahzuni. The correlation of the human development index (HDI) towards economic growth (GDP per capita) in 10 ASEAN member countries. JHSS (Journal of Humanities and Social Studies), Volume 2 (2), 40-46. (2018) 